\title{
To study the efficacy of Murchit Til Taila in management of Sandhigata Vata - a single case study
}

\section{Yadav Sunita ${ }^{1}$, Pillai Vignesh $*^{2}$}

1. Fellowship Panchakarma, YMT Ayurved Medical College, sector 4, kharghar, Navi Mumbai-410210. Email id :- sunitay111.sy@gmail.com phone no :-9930509587

2. $2^{\text {nd }}$ year pg scholar, panchakarma , Ymt Ayurved Medical College and hospital, sector 4, kharghar, Navi Mumbai- 410210.

*Corresponding Author: Email id: vigfrndz@gmail.com; Ph. no :-9920683170

\section{ABSTRACT:-}

Sandhigatavata is described under vatavyadhi in all ayurvedic classical texts. Sandhigatavata is defined as a disease of sandhi (joint) with symptoms of joint pain, swelling in joints, pain during movement and in the later stage restricted movements of joints. In Allopathic science, the similar condition of joint is explained as osteoarthritis. Treatment provides symptomatic relief, but the underlying pathology remains unchecked due to the absence of effective drugs. In the management of Sandhigata Vata, all the Acharyas have described the employment of Bahya snehana, Swedana, Abhyantara Tikta snehapan Vasti treatment.

In this study, a female patient aged 57 years was admitted to the ipd of panchakarma department with complaints of bilateral knee joint pain, crepitus, restricted movement, swelling and general weakness since three years. She was diagnosed as dhatukshaya janya sandhigata vata also known as nirupstambhit sandhigata vata sthansansharya at janu sandhi. Murchit til taila has vatashamak and vedanasthapan \& balya property. Hence in this case murchit til tail was used in the patient for matra vasti, sarvang snehan swedan, as well as sthanik vasti for a period 15 days and the patient was assessed on bases of relief in symptoms at end of treatment. Significant result was found symptoms of sandhi shoola(b/l knee joint pain), sandhishotha(swelling in joints) vata purna druti sparsha (crepitus), Graha(restricted movement).

Keywords: sandhigata vata, matra vasti, sarvang snehan swedan, murchit til taila

\section{INTRODUCTION:-}

Pain is an unfavorable sensation that brings an individual to the physician due to a halt from his routine works. The condition is more painful when mobile joints such as Janusandhi (knee joint) of the body are involved due to Sandhigata Vata. The disease Sandhigata Vata is more prone to be affected to knee joint because it is most frequently involved joint in daily routine 
work, weight bearing joint of the body, and more prone to develop in overweight patients. In the pathogenesis of Sandhigata Vata, Vata Dosha dominant with symptoms such as Vedana (pain during joint movement) and Shotha (swelling).

The joint stiffness and crepitus (specific sound during joint movement) are symptoms that may be co-related in modern parlance with osteoarthritis (OA) of the knee joint. OA is the second most common rheumatologic problem and is the most frequent joint disease having prevalence of about 22-39\% in India. Among them, 29.8\% persons between 45 and 64 years of age group report diagnosed arthritis. ${ }^{[1]} \mathrm{OA}$ of the knee joint is seen most common in the clinical practice of elderly population. Below 45 years of age, this disease is common in men and involves one or two joints, while in female, 55 years of age, usually involving multiple joints. ${ }^{[2]} \mathrm{OA}$ is the most common form of arthritis and leading cause of chronic disability mostly in all the population. For the management of OA, patients need to take analgesics for daily and lifelong. In OA, surgical therapy-like knee joint replacement is very costly and even after surgery patient has to continue some medicine for a long duration. The use of analgesics and steroids in old age may produce adverse effects such as gastritis, hyperacidity, and sometimes renal failure. $^{[3]}$

In Allopathy science, mainly analgesics, anti inflammatory drugs or surgery are the options for the treatment of osteoarthritis. These do not give satisfactory relief and also cause great adverse effect.

In ayurveda Acharya Charaka has mentioned repeated use of snehana, svedana, Vasti and mrudu virechana for the treatment of Vatavyadhi ${ }^{[4]}$ He has not mentioned the treatment of Sandhigatavata separately. Acharya Sushruta has described specific treatment for the Sandhigata vata firstsnehana, upanaha, agnikarma, ban dhana and unmardana. ${ }^{[5]}$

Charaka refers to taila as 'marutaghana'. Taila is mentioned to reduce vata without increasing kapha. ${ }^{[6]}$ It also stabilizes the mansa dhatu. Acharya Sushruta mentions snehana (outer/internal) for management of Sandhigatava. Murchit til taila, has til taila as the base content along with drugs like Haritaki bhibitaki amlaki musta lodhra manjistha kevada which has vataghna along with balya properties. All the above factors inspired me to study the effect of murchit til taila matra vasti in sandhigata vata.

Vasti Chikitsa is considered the best management of vitiated vata . The panchkarma procedure of Vasti has been hailed as 'ardha chikitsa' by acharyas that Is, half of the whole treatment. ${ }^{[7]}$

Matra Vasti is a type of Anuvasana Vasti that can be given to almost everybody, in all the seasons, without any strict regime of ahara and vihara and it is nishpariharya i.e, it can be given with maximum ease and has no complication thereafter. ${ }^{[8]}$

\section{CASE REPORT:}

Single case study. 
A female patient aged 57 years came to opd of panchakarma department having complaints of Bilateral knee joint pain, swelling, stiffness, restricted movement, since last 3 years.

Associated complaints:- sandhishaithilya, sarvang gaurav, shrama, vibandham (constipation) since 1-2 years

k/c/o :- nil

no past surgical history

no past history of trauma.

\section{ON EXAMINATION:}

pulse ;- 68/min

bp :- 130/90 mmhg

temp ;- afebrile

jiva :- niram

agni :- visham

$\mathrm{Hb}-12.4 \mathrm{gms} \%$

RBS-112mgs\%

S.URIC ACID - 4.16mgs\%

CRP - negative

RA - negative kosta :- krur

prakruti :- vaat kaphaj

FAMILY HISTORY:

Not significant

MENSTRUAL HISTORY :

Menopause - since 5 years

SYSTEMIC EXAMINATION :

N.A.D.

RESPIRATORY EXAMINATION :

N.A.D.

PER ABDOMEN :

N.A.D.

Pathological investigations:-

$\mathrm{x}$ - ray of both knee joint in standing view:

degenerative changes seen in both knee joints.

Blood report :

Platelet count -1.9 lakhs cells/ cumm

ESR - 4/10 MM

Urine Routine - Normal

Sr.calcium:-7.9

ASSESSEMENT CRITERIA:-

Sarvang Gaurav:-

\begin{tabular}{|l|l|}
\hline & Grade \\
\hline No feeling of heaviness & 0 \\
\hline occasional feeling of heaviness not affecting daily routine & 1 \\
\hline Frequent feeling of heaviness mildly affecting daily routine & 2 \\
\hline feeling of heaviness throughtout the daymoderately affecting daily routine & 3 \\
\hline feeling of heaviness throughout the day daily routine totally hampered & 4 \\
\hline
\end{tabular}


Shool (joint pain)

\begin{tabular}{|l|l|}
\hline & Grade \\
\hline No pain & 0 \\
\hline Pain in joints routine movements normal & 1 \\
\hline Pain in joint, slight limitation of movements & 2 \\
\hline Pain in joint, limitations of movement with very reduced activity & 3 \\
\hline
\end{tabular}

Shrama - fatigue

\begin{tabular}{|l|l|}
\hline \multicolumn{1}{|c|}{ No fatigue } & grade \\
\hline Fatigue on doing work & 0 \\
\hline $\begin{array}{l}\text { Fatigue in carrying out routine } \\
\text { work }\end{array}$ & 1 \\
\hline Even without doing work & 3 \\
\hline
\end{tabular}

Vibhandam

\begin{tabular}{|l|l|}
\hline & Grade \\
\hline 1time/day & 0 \\
\hline 1 time/ 2days & 1 \\
\hline 1 time/ 3 days & 2 \\
\hline 1 time/ 4 days & 3 \\
\hline 1 time/ 5 days & 4 \\
\hline 1 time/ 6 days & 5 \\
\hline 1 time/7 days & 6 \\
\hline
\end{tabular}

Asthi sandhi baddhata (stiffness in bones and joints)

\begin{tabular}{|l|l|}
\hline & grade \\
\hline No stiffness & 0 \\
\hline Stiffness for few minutes relieved by mild movements & 1 \\
\hline Stiffness lasting 1 - 2 hrs routinue works are not disturbed & 2 \\
\hline Stiffness lasting for more than 2 hours mildly affecting the daily routine & 3 \\
\hline Episodes of stiffness lasting for 2 - 6 hours daily routine are hampered & 4 \\
\hline
\end{tabular}

Sandhi shaithailya - weakness of joints

\begin{tabular}{|l|l|}
\hline & Grade \\
\hline No feeling of weakness in joints & 0 \\
\hline $\begin{array}{l}\text { Mild feeling of weakness in joints patient can stand/ walk independently without } \\
\text { difficulty }\end{array}$ & 1 \\
\hline $\begin{array}{l}\text { Moderate feeling of weakness in joints patient can stand/walk independently with } \\
\text { difficulty }\end{array}$ & 2 \\
\hline Severe feeling of weakness in joints patient can stand/ walk only with support & 3 \\
\hline Severe feeling of weakness in joints. patient unable stand/ walk with support & 4 \\
\hline
\end{tabular}


MATERIALS AND METHODS:-

The procedure for murchit oil ${ }^{[9]}$ is as follows:-

The followings herbs, Haritaki bhibitaki amlaki musta lodhra manjistha ketakipushpa, kumari were taken in powdered form in equal quantity. Four parts of the til oil was taken. The oil was heated on a low flame till it started bubbling and continued till all the bubbles disapppear. After cooling the above powder and 16 parts decotion of same drugs were added. The entire mixture was heated on a low flame till all the water content in it is evaporated. The oil thus prepared was used for various panchkarma procedure.

\section{TREATMENT PROTOCOL:-}

1. Sarvang snehan with murchit til oil for 35 mins

2. Sarvang basph swedan for $20 \mathrm{mins}$

3. Stanik upnaha of dasang + sunti $\times 2$ days

4. Followed by ubhya janu vasti with murchit til oil $\times 10$ days

5. Matra vasti of murchit til oil $-60 \mathrm{ml}$ $\times 15$ days

\section{OBSERVATION AND RESULT:}

\begin{tabular}{|l|l|l|}
\hline SYMPTOMS & Before Treatment & After treatment \\
\hline sarvang gaurav & 1 & 0 \\
\hline Shool joint pain & 3 & 1 \\
\hline Shrama - fatigue & 2 & 1 \\
\hline Asthi sandhi baddhata (stiffness in bones and joints) & 2 & 1 \\
\hline Sandhi shaithailya - weakness of joints & 2 & 1 \\
\hline Vibhandam & 1 & 0 \\
\hline
\end{tabular}

It is observed that murchit tila was very much beneficial to reduce the intensity of vatapurna drutisparsha, shotha, shula, akunchan prasarna vedana. The effect was long lasting after follow up also.

\section{DISCUSSION:}

Sandhigata vata specially occurs in vriddha avastha in which dhatukshaya takes place which leads to vata prakopa. vata and asthi have ashraya ashrayi sambandha. ${ }^{[10]}$ In vriddha avastha increased vata diminishes the sneha from its asthi dhatu. Due to dimination of sneha, kha vaigunya occurs in asthi which is responsible for the cause of sandhigata vata in the weight bearing joints especially in janusandhi.

Murchit til taila contains manjishta which is vatashamak, shothgna sulhara and guru guna. Haridra and vibhitaki have vedanasthapana property. Joint stiffness is due to ruksha, sheeta guna of vata which in 
turn causes the kharatva of mansa, snayu, kandara of asthi leading to stiffness. this is reduced by ushna veerya dravya like manjistha , vibitaki, ketakipushpa. drug like haritaki \& aamalaki are brimhan, rasayan which are responsible for asthi poshan. ${ }^{[11]}$ Thus by giving strength to mansa, asthi dhatu \& kandra it increases stability of janu sandhi Murchit til taila has vatashamak, vedanasthapan \& balya property because of these properties of murchit til taila upashaya occurs.

Action of Matra Vasti is possibly by Anupravaranbhav of vastidravya i.e. sneha moves easily up to grahani, nabhi, katipradesh \&kukshi.It spreads all over body to drain out the morbid dosha .Veerya of sneha enters in systemic circulation \&may show their action in Mastishka may help in arresting disease process. Snehan mainly acts against ruksha guna caused by vata and due to its gur guna treats laghu guna of vayu and ushña guna takes care of the sheetala guna of vayu.

\section{CONCLUSION:-}

From the above case it is concluded that murchit til taila is significantly effective in management of sandhigata vata and also useful in symptoms associated with sandhigata vata. No any adverse effect was found during or after treatment.

\section{REFERENCES:}

1. Chopra A, Patil J, Bilampelly V, Relwani J, Tandale HS. The Bhigwan (India) COPCORD: Methodology in first information report. APLAR J Rheumatol. 1997;1:145-54.
2. Golwalla AF, Golwalla SA. 21st ed. Mumbai: Asia Publishing House; 1970. Medicine for Students; p. 1032.

3. Green GA. Understanding NSAIDs: From aspirin to COX-2. Clin Cornerstone. 2001;3:50-60. [PubMed]

4. Aacharya vidyadhar shukl \&pro. Ravidatta tripathi Charaka Samhita(2), New delhi, Chaukhamba Sanskrit Pratishthan,2010 Vatavyadhi Chikitsa Adhyaya. 28:75-83. pg no701.

5. Dr. Anant Ram Sharma, Sushruta Samhita (2), Varanasi,Chaukhamba surbharati prakashan,2012, Vatavyadhichikitsa Adhaya. 4(8),page 205

6. Aacharya vidyadhar shukl \&pro. Ravidatta tripathi,charak samhita, vol 1, new delhi, Chaukhamba Sanskrit pratishthan, 2009, page 199

7. Aacharya vidyadhar shukl \&pro. Ravidatta tripathi,charak samhita, vol 2, new delhi, Chaukhamba Sanskrit pratishthan, 2010,page 883

8. Aacharya vidyadhar shukl \&pro. Ravidatta tripathi,charak samhita, vol 2, new delhi, Chaukhamba Sanskrit pratishthan, 2010,page 915 
9. Vd. santosh kumar Sharma, RasaBhaishajya kalpana vigyana, jaipur,Publication Scheme, Tenth edition, 2010,page 451

10. Dr. Brahmanand Tripathi, Astanga Hrdayam,Sutrastana, delhi,
Chaukhamba

Sanskrit

pratishthan,2007, page 165

11. Dr. Mansi makarand deshpande \& Dr. A. P. deshpande ,Dravyaguna vigyana,vol 2 , delhi,chaukhamba Sanskrit pratishthan, 2009, page 152,159,209, 356, 373, 600 .

\section{Cite article:}

To study the efficacy of Murchit Til Taila in management of Sandhigata Vataa single case study Yadav Sunita, Pillai Vignesh

Ayurlog: National Journal of Research in Ayurved Science- 2018; (6)(6): 1-7 